УДК [378.147:332.2]:378.4(438)

DOI 10.31494/2412-9208-2019-1-1-321-329

\title{
Using the mobile technologies in the process of training specialists of specialty 193 "Geodesy and land management"
}

\section{Використання мобільних технологій у процесі навчання фахівців спеціальності 193 “Геодезія та землеустрій”}

\author{
Nelja Rusina, \\ Candidate of Pedagogical Sciences, \\ lecturer \\ Неля Русіна, \\ кандидат педагогічних наук, \\ викладач \\ https://orcid.org/0000-0001-5826-8788 \\ RusinaN@i.ua \\ Separated subdivision of NULES of \\ ВСП “Рівненський коледж НУБіП \\ Ukraine "Rivne college" \\ 44 Kopernyka St, \\ Rivne, 33000 \\ України", \\ вул Коперніка, 44, м. Рівне, \\ 33000
}

Original manuscript received March 17, 2019

Revised manuscript accepted April 04, 2019

\begin{abstract}
The research is devoted to the problems of interactive learning as a special form of cognitive activity organization, which has very specific and predictable goals. It is noted that the characteristic feature of the last decade was active using of mobile communications means and various electronic devices. The modern mobile phone has capabilities that are not inferior to entry level PCs, and in some cases - and medium power. In particular this applies to smart phones and personal communicators (pocket personal computers with means of communication). In this regard, the use of mobile learning technologies in the educational process of training specialists in geodesy and land management needs to be generalized and systematized. The purpose of the article was to analyze the main possibilities of implementation mobile technologies in higher education, as well as the experience of their using in the training process of specialists in the field of geodesy and land management. The essence of mobile learning is presented as an interactive technology on the basis of which the higher education institutions create new learning environment where students can access educational materials at anytime and anywhere, making the learning process more attractive, democratic, comfortable and stimulates the student to self-education and lifelong learning. The technology of creation of interactive learning game with the help of free Kahoot online service is analyzed. It is noted that the possibility of mobile learning services expand the range of active learning methods and increase interactivity in studying and consolidating the educational material of land management disciplines. Implementation of online services and organization the current testing on their basis have positive affect on the study of disciplines in the professional cycle. Particular attention is paid to positive motivation in education and interest of students in the discipline, willingness to use modern information and communication technology and mobile tools for learning.
\end{abstract}

Key words: Interactive learning, mobile tools, mobile learning, Google Forms mobile apps, Survey Monkey, Kahoot, Socrative, Plickers.

ICV 2017: 63.43 
Вступ. Стратегія пріоритетного розвитку системи освіти передбачає заходи з розробки і реалізації інформаційних освітніх технологій і методів навчання, зокрема дистанційних; науково-дослідної і науково-технічної діяльності в системі освіти, інтеграції науки і освіти; організації виробництва навчального і наукового устаткування, приладів і засобів навчання різного призначення тощо (Байраківський, 2006).

При цьому основні методичні інновації пов'язані із застосуванням активних або інтерактивних методик навчання. Інтерактивне навчання це спеціальна фрорма організації пізнавальної діяльності. Вона має на увазі цілком конкретні й прогнозовані цілі, одна з яких - створення комфортних умов навчання такими, за яких студент відчуває свою успішність, свою інтелектуальну спроможність, що робить продуктивним сам освітній процес. Суть інтерактивного навчання полягає в такій його організації, за якої практично всі студенти виявляються залученими до пізнавальної діяльності; вони мають можливість розуміти і рефлексувати з приводу того, що вони знають і думають (Прокопенко). Зазначимо, інтерактивні методи навчання, що базуються на IKT, спонукають студентів до пошукової, творчої діяльності, сприяють розвитку їхньої особистості, професійному становленню, створюють умови для формування якостей, які необхідні для взаємодії в сучасному суспільстві та майбутній трудовій діяльності.

Увагу сучасних дослідників привертають різні аспекти впровадження інформаційно-комунікаційних технологій в освітній процес. Так, проблемам використання ІКТ з метою підвищення ефективності самостійної роботи присвячено дослідження Н. Бойко та А. Байраківського, які зазначають, що це сприяє повнішому оволодінню системою знань та вмінь, розвиває творчу спрямованість пізнавальної діяльності, допомагає формуванню відповідних професійних i особистісних якостей (Байраківський, 2006).

Т. Поведа зазначає роль застосування інформаційнокомунікаційних технологій в освіті (Поведа, 2014): суттєво прискорює передавання знань і накопиченого технологічного та соціального досвіду людства не тільки від покоління до покоління, а й від однієї людини до іншої; дозволяють успішніше й швидше адаптуватися до навколишнього середовища, соціальних змін. Це дає кожній людині можливість одержувати необхідні знання як сьогодні, так і в постіндустріальному суспільстві; активне й ефективне впровадження цих технологій в освіту $є$ важливим чинником створення нової системи освіти.

Характерною рисою останнього десятиріччя стало активне використання засобів мобільного зв'язку та різноманітних електронних пристроїв. Сучасний мобільний телефон має можливості, що не поступаються комп'ютерам початкового рівня, а в деяких випадках - i середньої потужності. У першу чергу, це стосується смартфонів та персональних комунікаторів (КПК із засобами зв'язку). Поширеність серед користувачів мобільного зв'язку смартфонів та персональних комунікаторів, на думку відповідних фахівців, складає біля $10 \%$, і має 
чітку тенденцію до зростання (Шокалюк).

Тому використання мобільних технологій відкриває нові можливості для навчання, особливо для тих, хто живе ізольовано або у віддалених від освітніх центрів місцях, постійно подорожує і стикається 3 труднощами в межах традиційного навчання (Триус, 2012). У зв'язку 3 цим питання використання технологій мобільного навчання в освітньому процесі підготовки фахівців геодезії та землеустрою потребують узагальнення та систематизації.

Мета статті - проаналізувати основні можливості впровадження мобільних технологій у вищій школі, а також досвід їх використання в освітньому процесі підготовки фахівців галузі геодезії та землеустрою.

Методи та методики дослідження. Для реалізації мети використовувався комплекс взаємопов'язаних методів дослідження, зокрема: системний, структурно-функціональний, аналітичний. Методологічною основою дослідження слугували провідні положення теорії пізнання, загальнонаукові підходи і принципи.

Результати та дискусії. Мобільне навчання відбувається на основі сучасних педагогічних, інформаційних і телекомунікаційних технологій та дозволяє створити відкрите інформаційне середовище. Розвиток системи мобільного навчання варто розглядати в контексті єдиного національного освітньо-наукового інформаційного простору, що дозволить приєднатися Україні до Європейських освітньо-наукових комп'ютерних мереж та інформаційних ресурсів.

Термін "мобільне навчання" відноситься до використання пристроїв, таких, як мобільні телефони, ноутбуки, планшети тощо. Існує декілька визначень терміна "мобільне навчання": це передача знань на мобільний пристрій із використанням мобільних технологій, тобто головним $€$ можливість виходу в Інтернет (Байраківський, 2006); це технології, які дозволяють організувати процес навчання за допомогою пристроїв мобільного зв'язку, наприклад, мобільних телефонів, тобто вихід в Інтернет не $є$ ключовим (Іщенко, 2005); це процес навчання, який $\epsilon$ різновидом дистанційного навчання, для реалізації якого знання передаються на персональні пристрої студентів (Бугайчук, 2008); це нова освітня парадигма, на основі якої виникає нове навчальне середовище, де студенти можуть отримати доступ до навчальних матеріалів у будьякий час та будь-де, що робить сам освітній процес всеосяжним і мотивує студентів спеціальностей до навчання протягом життя (Демкин, 2003).

Упровадження мобільного навчання передбачає застосування мобільних пристроїв у підготовці фрахівців, серед яких (Карполенкова, 2012):

- мобільні телефони в якості фото- чи відеокамери для фотографування навчальних матеріалів, записів лекцій із фахових дисциплін на відео, диктофон для встановлення алгоритмів та способів розв'язування практичних завдань;

- sms-розсилка як швидкий та простий спосіб повідомлення про термінові зміни, наприклад, щодо домашнього завдання чи заміни, спосіб 
підказок формул для геодезичних розрахунків;

- доступ до Інтернету через веб-браузер для перегляду відео пояснень щодо вирішення правових задач на YouTube;

- використання електронної пошти для спілкування й обміну інформацією у сфрері геодезії та землеустрою щодо вирішення практичних завдань;

- Skype, чат-конференції як спосіб соціальної інтеграції та взаємодії між викладачем та студентами землевпорядних спеціальностей;

- прикладні програми для виконання геодезичних розрахунків.

На сьогодні існує досить велика кількість мобільних додатків, орієнтованих на різний тип пристроїв та їх програмне забезпечення. Найбільш поширеними мобільними додатками, платформами та ресурсами є: Google Forms, Survey Monkey, Kahoot, Socrative, Plickers та багато інших. Означені програми можуть працювати в різних операційних системах (Windows, Linux, Android), що забезпечує можливість для студента відповідати на контрольні запитання або проходити тест із власного мобільного пристрою, а не стаціонарного комп'ютера закладу освіти.

Google Forms - програма із побудови великих за обсягом тестів із запитаннями різних типів і може застосовуватись для роботи з групою в аудиторії, а також для дистанційного опитування протягом тривалого часу. Обидва варіанти передбачають відповіді здобувачів освіти 3 власних мобільних пристроїв.

Kahoot, Socrative та Plickers орієнтовані на швидку обробку результатів тестування чи опитування. Це особливо важливо під час використання викладачем орієнтувальної функції перевірки знань на аудиторних заняттях.

Безкоштовний онлайн-сервic Kahoot - програма зі створення інтерактивних навчальних ігор: вікторин, обговорень, опитувань. Такі форми роботи застосовують у навчанні для перевірки знань студентів, а також для різних форм наукової, методичної та організаційної роботи. Участь в іграх, створених за допомогою сервісу, сприяє спілкуванню та співпраці в студентському колективі, підвищує рівень обізнаності 3 інформаційно-комунікаційними технологіями, стимулює критичне мислення.

Сервіс пропонує чотири форми гри (рис. 1). 


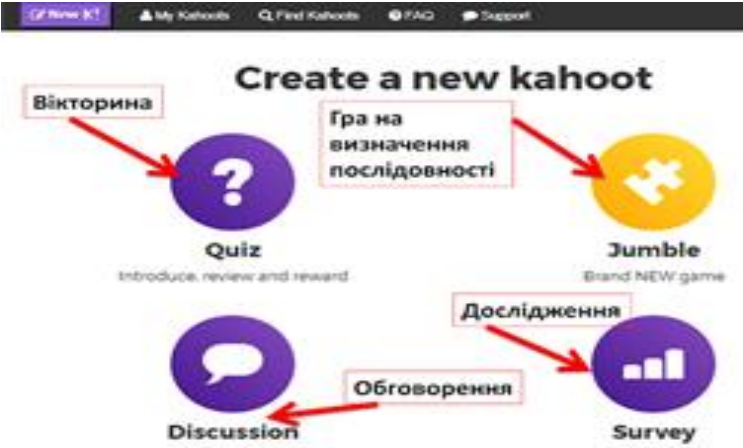

Рис. 1. Інтерфейс КАНООТ “Вибір форми гри”

Вибір форми забезпечує мета створення гри, зокрема: визначити рівень ознайомленості учасників із тією чи іншою темою або рівень їі розуміння - вікторина (Quiz); влаштувати дискусію щодо певного питання, презентувати ідею й отримати про неї “зворотній зв'язок" - обговорення (Discussion); зібрати думки, погляди учасників на ту чи іншу проблему опитування (Survey); створити гру із завданнями на визначення послідовності - дослідження (Jumble).

Для роботи студентів 3 цією платформою викладач спочатку створює та налаштовує тест (рис. 2, 3). Гра розпочинається, коли студенти вводять на своїх пристроях (планшеті, смартфоні, десктопі, ноутбуці) згенерований системою код та власне ім'я. Онлайн-сервіс Kahoot працює в браузері, доступний для всіх пристроїв, які можна підключити до мережі Internet.

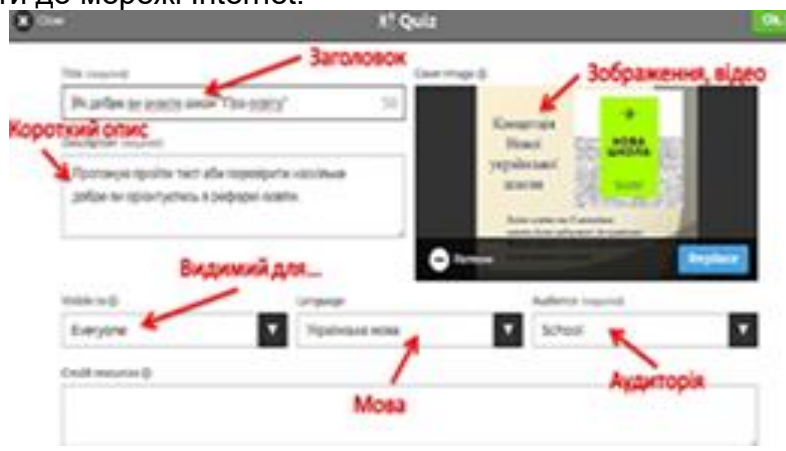

Рис. 2. Вікно вікторини

Система не потребує встановлення додатків на телефони - вона адаптована до мобільних пристроїв. Результати тестувань зберігаються у вигляді списку в таблиці MS Excel. Отже, викладач має можливість проводити моніторинг знань студентів. 
Серія: Педагогічні науки. - Вип.1. - Бердянськ : БДПУ, 2019. - 406 с.

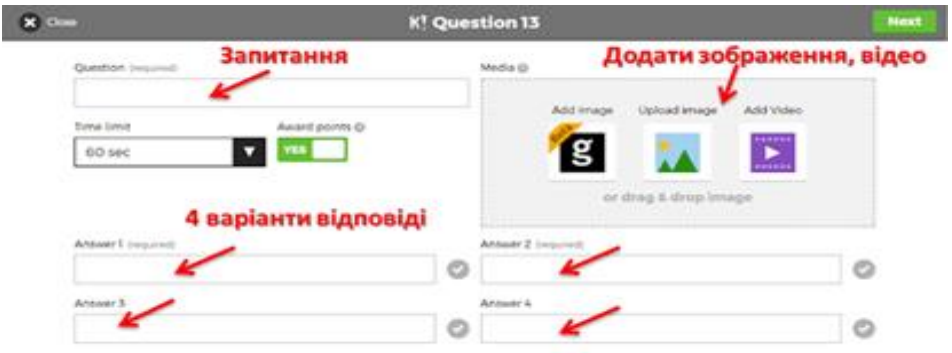

\section{Рис. 3. Вікно вікторини “Додання інформації"}

Безумовною перевагою цього сервісу $є$ система готових ігор, розроблених іншими користувачами сервісу. Тобто можна скористатися вправами, створеними самостійно або ж скопіювати завдання інших розробників (тести можна повторювати повністю чи змінювати якусь їх частину) (рис. 4).

Висновки. Таким чином, можливості сервісів мобільного навчання розширюють спектр активних методів та підвищують інтерактивність при вивченні та закріпленні навчального матеріалу землевпорядних дисциплін. Відповідно, впровадження онлайн-сервісів та організація на їх основі поточного тестування позитивно впливають на засвоєння дисциплін професійного циклу. Особливо відмічається позитивна мотивація в навчанні та зацікавленість студентів теоретичним матеріалом, готовність використовувати сучасні ІКТ та мобільні засоби для навчання.

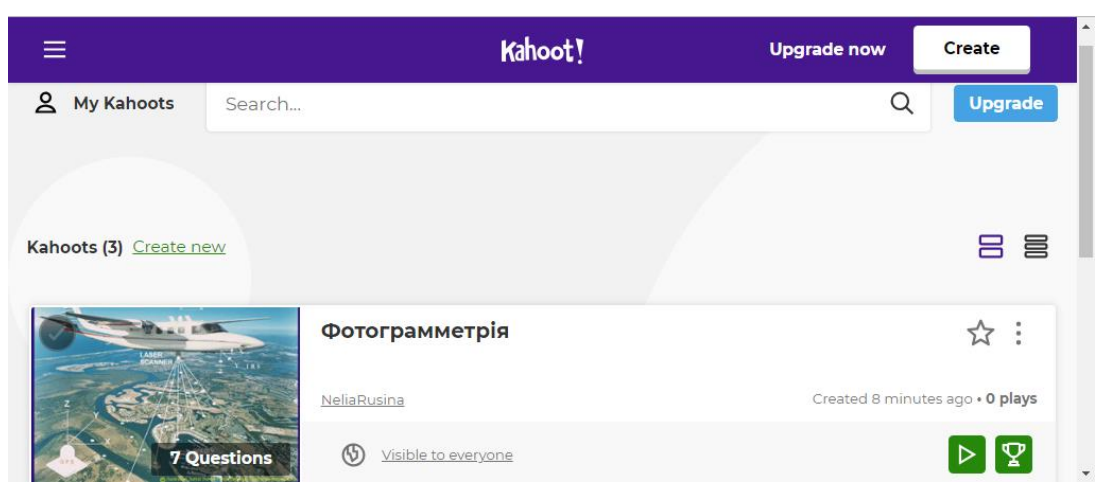




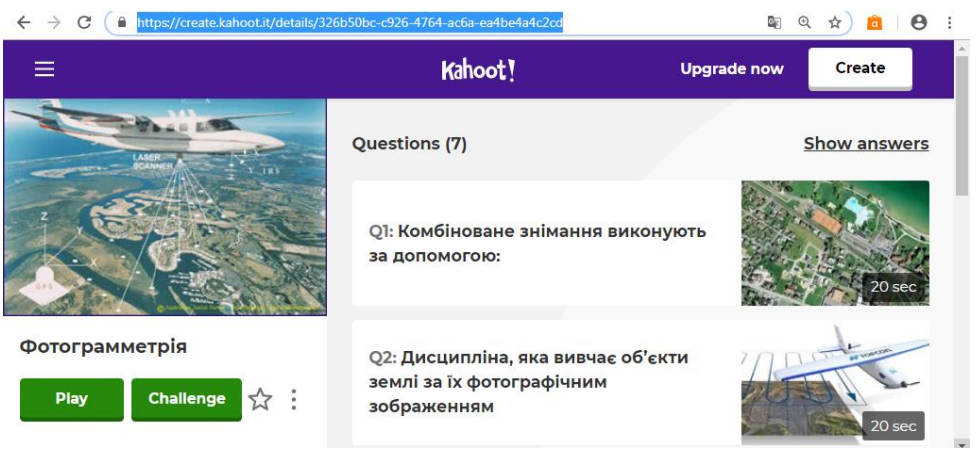

\section{Рис. 4. Вікно “Фотограмметрії”}

Перспективами подальшого дослідження $€$ систематизація педагогічного досвіду, класифікація розробок та укладання на цих засадах технологій, які сприятимуть підвищенню ефективності підготовки фахівців галузі “Геодезії та землеустрою" в закладах вищої освіти.

\section{Література}

1.Байраківський А. І. Особливості самостійної роботи студентів в умовах запровадження комп'ютерних технологій у навчальному процесі / Байраківський А. І., Бойко Н. І.// Болонський процес: трансформація навчального процесу у технології навчання: Матеріали III міжнародної науково-методичної конференції ДУІКТ. - К., 2006. - С. 247-251.

2.Бугайчук К. Л. Мобильное обучение в высшей школе / К. Бугайчук // Мобильное обучение. - 2008. - № 2. - С. 48-49.

3.Демкин В.П. Адаптивное обучение на основе информационных технологий [В.П.Демкин , Г.В.Можаева, А.Г.Яковлева ] // Телематика-2003. Труды Х Всероссийской научно методической конференции. - СПб., 2003. - Т.2. - с.400 - 401.

4.Іщенко О.А. Передумови й проблеми застосування нових інформаційних технологій при викладанні суспільно-гуманітарних дисциплін / О.А. Іщенко // Коледжанин - 2002. . - №3. -С.33-34.

5.Карполенкова І. В. Дистанційне навчання : переваги та недоліки / І. В. Карполенкова // Фізика в школах України. - 2012. - № 8. - С. 14-18.

6.Поведа Т.П. Удосконалення процесу вивчення курсу “Безпеки життєдіяльності" в університеті засобами інформаційно-комунікаційних технологій / Т. П. Поведа // Збірник наукових праць Кам'янець-Подільського національного університету ім. Івана Огієнка. Серія : Педагогічна. - 2014. - Вип. 20. - С. 106-108. - Режим доступу: http://nbuv.gov.ua/UJRN/znpkp_ped_2014_20_36

7.Прокопенко С.В. Впровадження інтерактивних методів і прийомів навчання на уроках біології [Електронний документ ]/ С.В. Прокопенко. - Режим доступу: http://virtkafedra.ucoz.ua/el gurnal/pages/vyp14/Prokopenko.pdf

8.Триус Ю.В. Організаційні й технічні аспекти використання систем мобільного навчання [Електронний документ]/ Ю.В.Триус, В.М.Франчук, Н.П.Франчук. - Режим доступу: file:///C:/Users/User/ Downloads/Nchnpu 2201212 8.pdf

9.Шокалюк С.В. Мобільне навчання: завжди та всюди [Електронний документ]/ С.В.Шокалюк, О.І.Теплицький, І.О.Теплицький, С.О.Семеріков. - Режим доступу: http://elibrary.kdpu.edu.ua/jspui/handle/0564/927 


\section{References}

1.Bairakivskyi A. I. Osoblyvosti samostiinoi roboty studentiv v umovakh zaprovadzhennia kompiuternykh tekhnolohii $u$ navchalnomu protsesi [Features of independent work of students in the conditions of introduction of computer technologies in the educational process] / Bairakivskyi A. I., Boiko N. I.// Bolonskyi protses: transformatsiia navchalnoho protsesu $u$ tekhnolohii navchannia: Materialy III mizhnarodnoi naukovo-metodychnoi konferentsii DUIKT [Bologna Process: Transforming the Learning Process into Learning Technology: Materials of the III International Scientific and Methodological Conference of the DUIKT]. - K., 2006. S. 247-251 [in Ukrainian] .

2.Buhaichuk K. L. Mobilnoe obuchenie v vysshey shkole [Mobile learning in high school] / K. Buhaichuk // Mobilnoe obuchenie [Mobile learning]. - 2008. - № 2. S. 48-49 [in Russian] .

3.Demkyn V.P. Adaptivnoe obuchenie na osnove informatsionnykh tekhnologiy [Adaptive learning based on information technology]/ [V.P.Demkyn , H.V. Mozhaeva, A.H.Yakovleva ] // Telematika-2003. Trudy X Vserossiyskoy nauchno metodicheskoy konferentsii [Telematics 2003 Proceedings of the X All-Russian Scientific Methodical Conference]. -SPb, 2003. -V.2.-S.400 - 401 [in Russian] .

4.Ishchenko O.A. Peredumovy y problemy zastosuvannia novykh informatsiinykh tekhnolohii pry vykladanni suspilno-humanitarnykh dystsyplin [Prerequisites and problems of application of new information technologies in the teaching of social and humanitarian disciplines]/ O.A. Ishchenko // Koledzhanyn [Kolejanin] - 2002. . - №3. -S.33-34[in Ukrainian].

5. Karpolenkova I. V. Dystantsiine navchannia : perevahy ta nedoliky [Distance Learning: Advantages and Disadvantages]/ I. V. Karpolenkova // Fizyka v shkolakh Ukrainy [Physics in schools of Ukraine]. - 2012. - № 8. - S. 14-18/[in Ukrainian]

6.Poveda T.P. Udoskonalennia protsesu vyvchennia kursu «Bezpeky zhyttiediialnosti» $v$ universyteti zasobamy informatsiino-komunikatsiinykh tekhnolohii [Improving the process of studying the course "Safety of Life" at the University by means of information and communication technologies] /T. P. Poveda // Zbirnyk naukovykh prats Kamianets-Podilskoho natsionalnoho universytetu im. Ivana Ohiienka. Seriia : Pedahohichna [Collection of scientific works of the Kamyanets-Podilsky National University. Ivan Ogienko Series: Pedagogical]. - 2014. - Vyp. 20. - S. 106-108. Rezhym dostupu: http://nbuv.gov.ua/UJRN/znpkp ped 20142036 [in Ukrainian]

7.Prokopenko S.V. Vprovadzhennia interaktyvnykh metodiv i pryiomiv navchannia na urokakh biolohii [Implementation of interactive methods and methods of training in the lessons of biology] [Elektronnyi dokument ] / S.V. Prokopenko. - Rezhym dostupu: http://virtkafedra.ucoz.ua/el gurnal/pages/vyp14/Prokopenko.pdf[in Ukrainian]

8.Tryus Yu.V. Orhanizatsiini y tekhnichni aspekty vykorystannia system mobilnoho navchannia [Organizational and technical aspects of the use of mobile education systems] [Elektronnyi dokument]/Yu.V.Tryus, V.M.Franchuk, N.P.Franchuk. Rezhym dostupu: file:///C:/Users/User/Downloads/Nchnpu 2201212 8.pdf [in Ukrainian]

9.Shokaliuk S.V. Mobilne navchannia: zavzhdy ta vsiudy[Mobile learning: always and everywhere] [Elektronnyi dokument]/ S.V.Shokaliuk, O.I.Teplytskyi,

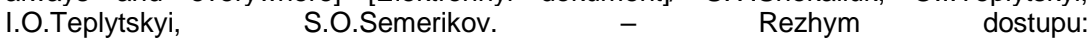
http://elibrary.kdpu.edu.ua/jspui/handle/0564/927[in Ukrainian]

\footnotetext{
АНОТАЦІЯ

Стаття присвячена питанням інтерактивного навчання як спеціальній формі організації пізнавальної діяльності, яка має цілком конкретні й прогнозовані цілі. Зазначено, що характерною рисою останнього десятиріччя
} 
стало активне використання засобів мобільного зв'язку та різноманітних електронних пристроїв. Сучасний мобільний телефон має можливості, що не поступаються комп'ютерам початкового рівня, а в деяких випадках - i середньої потужності. У першу чергу, це стосується смарторонів та персональних комунікаторів (КПК із засобами зв'язку). У зв'язку з цим питання використання технологій мобільного зв'язку в освітньому процесі підготовки фрахівців геодезії та землеустрою потребують узагальнення та систематизації. Метою статmі стали питання аналізу основних можливостей упровадження мобільних технологій у вищій школі, а також досвід їх використання під час підготовки фрахівців галузі геодезії та землеустрою. Представлено сутність поняття мобільного навчання як інтерактивну технологію, на основі якої у ЗВО створюють нове навчальне середовище, де студенти можуть отримати доступ до навчальних матеріалів у будь-який час та в будь-якому місці, що робить процес навчання більш привабливим, демократичним, комфортним і стимулює студента до самоосвіти та навчання протягом усього життя. Проаналізовано технологію створення інтерактивної навчальної гри за допомогою безкоштовного онлайн-сервісу Kahoot. Відзначено, що можливості сервісів мобільного навчання розширюють спектр методів активного навчання та підвищують активність при вивченні та закріпленні навчального матеріалу землевпорядних дисциплін. Упровадження онлайнсервісів та організація на їх основі поточного тестування позитивно впливають на вивчення дисциплін профресійного циклу. Особливо відмічається позитивна мотивація та зацікавленість студентів навчальною дисципліною, готовність використовувати сучасні ІКТ та мобільні засоби.

Ключові слова: Інтерактивне навчання, мобільні засоби, мобільне навчання, мобільні додатки Google Forms, Survey Monkey, Kahoot, Socrative, Plickers. 